\title{
Shifts in bryophyte carbon isotope ratio across an elevation $\times$ soil age matrix on Mauna Loa, Hawaii: do bryophytes behave like vascular plants?
}

\author{
Mashuri Waite $\cdot$ Lawren Sack
}

Received: 27 March 2010/Accepted: 28 December 2010/Published online: 29 January 2011

(C) The Author(s) 2011. This article is published with open access at Springerlink.com

\begin{abstract}
The carbon isotope ratio $\left(\delta^{13} \mathrm{C}\right)$ of vascular plant leaf tissue is determined by isotope discrimination, primarily mediated by stomatal and mesophyll diffusion resistances and by photosynthetic rate. These effects lead to predictable trends in leaf $\delta^{13} \mathrm{C}$ across natural gradients of elevation, irradiance and nutrient supply. Less is known about shifts in $\delta^{13} \mathrm{C}$ for bryophytes at landscape scale, as bryophytes lack stomata in the dominant gametophyte phase, and thus lack active control over $\mathrm{CO}_{2}$ diffusion. Twelve bryophyte species were sampled across a matrix of elevation and soil ages on Mauna Loa, Hawaii Island. We tested hypotheses based on previous findings for vascular plants, which tend to have less negative $\delta^{13} \mathrm{C}$ at higher elevations or irradiances, and for leaves with higher leaf mass per area (LMA). Across the matrix, bryophytes spanned the range of $\delta^{13} \mathrm{C}$ values typical of $\mathrm{C}_{3}$ vascular plants. Bryophytes were remarkably similar to vascular plants in exhibiting less negative $\delta^{13} \mathrm{C}$ with increasing elevation, and with lower overstory cover; additionally $\delta^{13} \mathrm{C}$ was related to bryophyte canopy projected mass per area, a trait analogous to LMA in vascular plants, also correlated negatively with
\end{abstract}

Communicated by Robert Pearcy.

Electronic supplementary material The online version of this article (doi:10.1007/s00442-010-1903-y) contains supplementary material, which is available to authorized users.

M. Waite · L. Sack

Department of Botany, University of Hawaii,

3190 Maile Way, Honolulu, HI 96822, USA

L. Sack $(\bowtie)$

Department of Ecology and Evolutionary Biology,

University of California, Los Angeles, 621 Charles E.

Young Drive South, Los Angeles, CA 90095-1606, USA

e-mail: lawrensack@ucla.edu overstory cover. The similarity of responses of $\delta^{13} \mathrm{C}$ in bryophytes and vascular plants to environmental factors, despite differing morphologies and diffusion pathways, points to a strong direct role of photosynthetic rate in determining $\delta^{13} \mathrm{C}$ variation at the landscape scale.

Keywords Altitudinal gradient · Elevation · Hawaii · Liverworts · Moss

\section{Introduction}

Foliar carbon isotope ratio $\left(\delta^{13} \mathrm{C}\right)$ can reflect ecology and physiology, especially because in vascular plants $\delta^{13} \mathrm{C}$ reflects changes in function along resource gradients. Less is known about bryophyte $\delta^{13} \mathrm{C}$ responses. We aimed to quantify the degree to which bryophytes resemble vascular plants (tracheophytes) in their landscape scale $\delta^{13} \mathrm{C}$ using the bryophyte flora distributed across Mauna Loa, Hawaii, a "natural experiment" for ecological research (Vitousek 2004).

Differences in the relative abundance of ${ }^{13} \mathrm{C}$ and ${ }^{12} \mathrm{C}$ in plant tissues relative to the atmosphere is caused by discrimination against the heavier ${ }^{13} \mathrm{C}$ during photosynthesis by the carbon fixing enzyme RubisCO and during diffusion through air and liquid water (Farquhar et al. 1989). The $\delta^{13} \mathrm{C}$ is negatively related to discrimination; $\delta^{13} \mathrm{C}$ increases as the chloroplast $\mathrm{CO}_{2}$ concentration $\left(c_{\mathrm{c}}\right)$ declines and carboxylation discriminates less against ${ }^{13} \mathrm{C}$ (Farquhar and Sharkey 1982). The $c_{\mathrm{c}}$ can be affected by several factors which influence $\mathrm{CO}_{2}$ drawdown by photosynthesis relative to its rate of diffusion to the chloroplast. A high photosynthetic assimilation rate $(A)$ draws down $c_{\mathrm{c}}$ relative to the $\mathrm{CO}_{2}$ concentration of source air $\left(c_{\mathrm{a}}\right)$ (Farquhar et al. 1989). Vascular plants control $\mathrm{CO}_{2}$ diffusion into the leaf with their stomata, which respond to numerous factors, 
especially opening with irradiance and high leaf water status, and closing under opposite conditions. A lower stomatal conductance $\left(g_{\mathrm{s}}\right)$ or a lower mesophyll conductance should reduce $c_{\mathrm{c}} / c_{\mathrm{a}}$ and lead to higher $\delta^{13} \mathrm{C}$ (Loreto et al. 1992; DeLucia et al. 2003; Seibt et al. 2008; Niinemets et al. 2009). Bryophytes differ from vascular plants fundamentally in lacking stomata in the dominant life stage (Schofield 1985), but span a wide range of $\delta^{13} \mathrm{C}$ from -21 to $-40 \%$ (but primarily -22 to $-32 \%$; Rundel et al. 1979; Proctor et al. 1992; Fletcher et al. 2004), very similar to $\mathrm{C}_{3}$ tracheophytes, which range from -24 to $-32 \%$ (O’Leary 1988).

In vascular plants, $\delta^{13} \mathrm{C}$ tends to correlate with resource gradients for given species and across species sets. Typically, $\delta^{13} \mathrm{C}$ increases with elevation, associated with higher leaf mass per area (LMA) at lower temperatures (see below; Körner et al. 1988, 1991, 2003; Vitousek et al. 1990; Cordell et al. 1999). The $\delta^{13} \mathrm{C}$ also tends to correlate negatively with water availability, due to stomatal closure at low water availability (Farquhar et al. 1989). Further, vascular plant canopies exhibit increasing foliar $\delta^{13} \mathrm{C}$ with height (Medina and Minchin 1980; Garten and Taylor 1992; Ometto et al. 2006) due to effects linked with three resource gradients. According to the "water stress- $g_{\mathrm{s}}$ effect", higher irradiance with increasing canopy height (CH) may be associated with lower leaf water status, and lower $g_{\mathrm{s}}$ and $c_{\mathrm{c}}$ (Niinemets et al. 2004). According to the "irradiance-A effect", high irradiance may drive higher $A$ relative to $g_{\mathrm{s}}$, decreasing $c_{\mathrm{c}}$ (Brooks et al. 1997; Le Roux et al. 2001; Duursma and Marshall 2006). Finally, according to the "source air effect", $\delta^{13} \mathrm{C}$ may vary across natural irradiances due to a vertical gradient in air $\delta^{13} \mathrm{C}$ caused by soil respiration (Francey et al. 1985; Schleser and Jayasekera 1985; Ehleringer et al. 1986; Farquhar et al. 1989; Medina et al. 1991; Buchmann et al. 1997b; Sternberg et al. 1989, 1997; Schedlbauer and Kavanagh 2008); this effect is dampened by air mixing and typically accounts for only ca. 10-30\% of the difference in foliar $\delta^{13} \mathrm{C}$ from understory to top-of-canopy (Broadmeadow et al. 1992; Brooks et al. 1997; Buchmann et al. 1997a, 2002; Sternberg et al. 1997).

Bryophytes may follow similar trends in $\delta^{13} \mathrm{C}$ with gradients as tracheophytes. The $\delta^{13} \mathrm{C}$ may correlate positively with elevation, as reported for Sphagnum (MenotCombes et al. 2004; Skrzypek et al. 2007), potentially arising because of a "temperature effect" if lower temperature at high elevation reduces respiration relative to $A$, leading to reduced loss of the heavier isotope (cf. Gillon and Griffiths 1997; Barbour and Hanson 2009), thus reducing discrimination (Hamerlynck et al. 2002; Skrzypek et al. 2007), and/or because of lower atmospheric pressure leading to lower $c_{\mathrm{c}}$ (Menot and Burns 2001). A positive correlation of bryophyte $\delta^{13} \mathrm{C}$ with water availability has also been shown due to "liquid film effect" that reduces $\mathrm{CO}_{2}$ diffusion (Proctor et al. 1992; Rice and Giles 1996; Williams and Flanagan 1996; Meyer et al. 2008). Bryophytes may also show increased $\delta^{13} \mathrm{C}$ with higher irradiance as found for the moss Tortula ruralis (Hamerlynck et al. 2002) and for three liverworts (Fletcher et al. 2006). This pattern could arise from the "irradiance-A effect" and/or from the "source air effect", if forest floor bryophytes experience elevated $\mathrm{CO}_{2}$ originating from soil respiration (DeLucia et al. 2003).

The $\delta^{13} \mathrm{C}$ may also relate to leaf structure and composition. Across species of tracheophytes, $\delta^{13} \mathrm{C}$ correlates positively with LMA and nitrogen concentration per area $\left(N_{\text {area }}\right)$, themselves related (Hultine and Marshall 2000; Takahashi and Miyajima 2008; Li et al. 2009). A similar pattern was found for the Hawaiian tree Metrosideros polymorpha across elevations: $\delta^{13} \mathrm{C}$ positively correlated with LMA, apparently due to higher carboxylation rate related to the higher $N_{\text {area }}$ (Vitousek et al. 1990; Cordell et al. 1998, 1999). In bryophytes, canopy mass per ground area (CMA) is analogous to tracheophyte LMA (Waite and Sack 2010) and may be related to higher $N$ per ground area, and hence bryophyte $\delta^{13} \mathrm{C}$ might be expected to correlate with CMA.

Previous work has highlighted trends for a few bryophyte species along specific gradients. In a previous study, we found strong variation in bryophyte $\mathrm{N}$ and $\mathrm{P}$ stoichiometry on Mauna Loa (Waite and Sack 2011). Here, we conducted a landscape-scale analysis of variation in $\delta^{13} \mathrm{C}$ within and across species, and its correlation with climate (temperature and precipitation), forest and soil development, and overstory cover (OC). We also determined the correlation of $\delta^{13} \mathrm{C}$ with other functional traits and nutrient composition. Based on patterns within and across tracheophyte species, we hypothesized bryophyte $\delta^{13} \mathrm{C}$ would increase at (1) higher elevation, (2) higher irradiance, (3) lower precipitation and (4) higher CMA.

\section{Materials and methods}

Study site, species and sampling

Sampling took place across an elevational gradient on the windward slope of Mauna Loa, Hawaii Island, a model system for studies of ecosystem development (Vitousek et al. 1995; Raich et al. 1997). Mean annual temperature (MAT) declines with elevation on this slope at a lapse rate of $6.4^{\circ} \mathrm{C} / \mathrm{km}$ (Juvik and Nullet 1994). Bryophytes were sampled at six elevations (287-2,239 m) on young lava flows (126-152 years old) and old lava flows $(\geq 3,400$ years old; Lockwood et al. 1988) at ten sites (Table 1; Fig. 1). Bryophytes occupied seven primary 
substrates (bark, humus, leaf litter, rock, soil, rotted wood, and tree fern trunk), and accounted for $10-80 \%$ of surface cover.

Eleven moss and one liverwort species were collected at ten sites (Table 1). Species were chosen that were sufficiently common to allow collection of replicates at given sites. The species varied in elevational range; the extreme cases were Campylopus incarvatus, found only at the 700 m old flow site, and Racomitrium lanuginosum, which, like the dominant tree species $M$. polymorpha, occurred at all sampled elevations. We collected samples of $40-150 \mathrm{~cm}^{2}$ in projected area from three colonies per species, where possible, at each site (in 6 of 53 cases only a single colony was found for a given species). The projected area of each sample was traced on clear plastic and scanned (300 dots per inch; Epson 3170 Photo Scanner; Seiko Epson, Nagano, Japan) for area determination (using ImageJ 1.42q software; US National Institutes of Health, Bethesda, MD, USA). The substrate and the estimated height above ground for epiphytic colonies were recorded to the nearest $10 \mathrm{~cm}$; non-epiphytic colonies were collected from rocks, fallen logs, and the ground surface. Samples were brought to the laboratory in plastic bags (Ziploc; SC Johnson, Racine, WI, USA) on ice and refrigerated until processing.

\section{Climate data and overstory cover}

We estimated the climate at each sampling site using a Geographic Information System model based on climate station data (Cao et al. 2007) and Geographic Positioning System coordinates (GPSmap 60CSx; Garmin, Olathe, KS, USA). We estimated mean annual temperature (MAT), precipitation (MAP), relative humidity (MARH) and vapor pressure deficit (VPD), calculated from MAT and MARH (Campbell and Norman 1998). VPD is a measure of atmospheric drought, i.e., the driving force for evaporation, and can be calculated as an absolute pressure difference (in $\mathrm{kPa}$ of vapor) or after normalizing by atmospheric pressure (mole fraction; i.e., unitless); the mole fraction VPD accounts for the effects of atmospheric pressure and temperature on diffusibility and thus more clearly indicates differences in driving force across elevations. Across sites the mole fraction VPD correlated strongly with absolute VPD ( $r=0.92 ; P<0.001)$, and the two estimates correlated similarly with other measured traits; only relationships with absolute VPD are presented. Forest overstory cover (OC, \%), the proportion of the sky obscured from view (equivalent to canopy closure in Jennings et al. 1999), was visually assessed, to the nearest $10 \%$. Visual canopy cover estimates involve a level of uncertainty, but correlate with measurements using a densiometer or hemispherical photography (Schott and Pieper 1985; Vora 1988; Bellow and Nair 2003; Korhonen et al. 2006), especially given training as was undertaken previously to this study, to achieve a correspondence of $\pm 5 \%$ relative to hemispherical photos (Teti and Pike 2005; Korhonen et al. 2006; Paletto and Tosi 2009).

Measurements of structure, nutrient concentrations and $\delta^{13} \mathrm{C}$

$\mathrm{CH}$ was determined with a ruler to the nearest $\mathrm{mm}$ of the green portion of the canopy at three random positions in each sample. The upper, green portions of the stems were cut from the older brown tissue using a razor blade, dried at $80^{\circ} \mathrm{C}$ for at least $48 \mathrm{~h}$ before determination of dry mass (AB204S/FACT Analytical Balance; Mettler Toledo, Columbus, OH, USA). Canopy mass per area (CMA) was determined by dividing dry mass by ground area. Dried samples were analyzed for $\delta^{13} \mathrm{C}$, nitrogen per mass $\left(N_{\text {mass }}\right)$ and carbon per mass using high temperature combustion in an elemental analyzer (Costech ECS 4010; Valencia, CA, USA), with effluent passed into a continuous flow isotope ratio mass spectrometer (ThermoFinnigan Delta V Advantage with a Conflo III interface; ThermoFisher Scientific, Waltham, MA, USA; Fry et al. 1996). Samples were dry ashed in glass vials (Miller 1998), dissolved in $1 \mathrm{~N} \mathrm{HCL}$ and analyzed for phosphorus per mass $\left(P_{\text {mass }}\right)$ using inductively coupled plasma-optical emission spectroscopy (Varian Vista MPX Instrument; Varian, Palo Alto, CA, USA; Porder et al. 2005). Concentrations of nitrogen and phosphorus per ground area $\left(N_{\text {area }}\right.$ and $\left.P_{\text {area }}\right)$ were determined as, respectively, $N_{\text {mass }}$ and $P_{\text {mass }}$ multiplied by CMA. N:P was determined by dividing $N_{\text {mass }}$ by $P_{\text {mass }} ; \mathrm{C}: \mathrm{N}$ and $\mathrm{C}: \mathrm{P}$ by dividing carbon per mass by, respectively, $N_{\text {mass }}$ and $P_{\text {mass }}$.

\section{Statistical analyses}

Statistical procedures were applied using R 2.6.1 ( $\mathrm{R}$ Development Core Team 2007). We tested for differences in $\delta^{13} \mathrm{C}$ across elevations, soil ages and species using threeway analysis of variance (ANOVA) and across substrate types using one-way ANOVA after log-transformation to improve normality and homoscedasticity (Zar 1999). Multiple pairwise camparisons of $\delta^{13} \mathrm{C}$ among substrate types was calculated with the Tukey honestly significant difference test (HSD; Zar 1999). Subsequent correlation analyses used species mean values for each site. Pearson correlations were determined for linear and power law relationships (i.e., linear relationships after log-transformation) for $\delta^{13} \mathrm{C}$ against environmental variables and bryophyte composition and structure variables. Relationships were tested for species mean values across all sites, and separately across only young and old soil ages 
Table 1 Bryophyte taxa and substrates sampled from young and/or old lava flows at seven elevations on Mauna Loa, Island of Hawaii, and the minimum, mean, and maximum values for average carbon isotope composition $\left(\delta^{13} \mathrm{C}\right)$ across individuals at the sampled sites, and modeled climates for each site

\begin{tabular}{|c|c|c|c|c|c|c|c|c|c|c|}
\hline \multirow[t]{2}{*}{ Taxa sampled } & \multirow[t]{2}{*}{ Family } & \multirow{2}{*}{$\begin{array}{l}\text { Substrate, average } \\
\text { height above } \\
\text { ground }(\mathrm{m})\end{array}$} & \multicolumn{7}{|c|}{ Elevations $(\mathrm{m})$ and soil ages sampled } & \multirow[t]{2}{*}{$\delta^{13} \mathrm{C}(\%)$} \\
\hline & & & 300 & 700 & 1,100 & 1,650 & 1,750 & 1,760 & 2,200 & \\
\hline Acroporium fusco-flavum & Sematophyllaceae & Leaf litter-bark, 0.4 & $\mathrm{Y}$ & $\mathrm{Y}, \mathrm{O}$ & $\mathrm{Y}, \mathrm{O}$ & $\mathrm{O}$ & $\mathrm{O}$ & & & $\begin{array}{l}-29.0,-30.4 \\
-32.2\end{array}$ \\
\hline Bazzania cf. trilobata & Lepidoziaceae & Bark-humus, 0.4 & & $\mathrm{Y}, \mathrm{O}$ & $\mathrm{Y}, \mathrm{O}$ & $\mathrm{O}$ & $\mathrm{O}$ & $\mathrm{O}$ & & $\begin{array}{l}-27.1,-29.5 \\
-31.0\end{array}$ \\
\hline Campylopus exasperatus & Dicranaceae & Rock, 0.4 & & $\mathrm{Y}$ & & & & & & -25.9 \\
\hline Campylopus hawaiicus & Dicranaceae & Humus-bark, 0.6 & & & $\mathrm{O}$ & $\mathrm{O}$ & $\mathrm{O}$ & $\mathrm{O}$ & & $\begin{array}{l}-27.6,-29.1 \\
-30.4\end{array}$ \\
\hline Campylopus incurvatus & Dicranaceae & Bark, 0.4 & & $\mathrm{O}$ & & & & & & -31.4 \\
\hline Campylopus schmidii & Dicranaceae & Rock, 0.4 & & & & & $\mathrm{O}$ & & & -27.5 \\
\hline Dicranum speirophyllum & Dicranaceae & Leaf litter-humus, 0.4 & & & $\mathrm{Y}$ & $\mathrm{Y}, \mathrm{O}$ & $\mathrm{O}$ & $\mathrm{O}$ & $\mathrm{O}$ & $\begin{array}{l}-28.7,-29.3 \\
-29.9\end{array}$ \\
\hline Leucobryum gracile & Dicranaceae & Bark-humus, 0.6 & $\mathrm{Y}$ & $\mathrm{O}$ & $\mathrm{O}$ & $\mathrm{O}$ & & $\mathrm{O}$ & & $\begin{array}{l}-30.2,-31.2 \\
-32.4\end{array}$ \\
\hline Leucobryum seemannii & Dicranaceae & Humus, 0.4 & $\mathrm{Y}$ & $\mathrm{O}$ & & & & & & $\begin{array}{c}-32.5,-32.5 \\
-32.6\end{array}$ \\
\hline Macromitrium microstomum & Orthotrichaceae & Bark, 1.8 & Y & $\mathrm{Y}, \mathrm{O}$ & $\mathrm{Y}, \mathrm{O}$ & $\mathrm{Y}, \mathrm{O}$ & $\mathrm{O}$ & $\mathrm{O}$ & & $\begin{array}{l}-28.2,-29.4 \\
-30.7\end{array}$ \\
\hline Pyrrhobryum spiniforme & Rhizogoniaceae & Bark-humus, 0.4 & & $\mathrm{O}$ & $\mathrm{O}$ & $\mathrm{O}$ & & $\mathrm{O}$ & & $\begin{array}{l}-28.2,-28.7 \\
-29.5\end{array}$ \\
\hline Racomitrium lanuginosum & Grimmiaceae & Rock, 0.4 & $\mathrm{Y}$ & $\mathrm{Y}$ & $\mathrm{Y}$ & $\mathrm{Y}$ & $\mathrm{O}$ & $\mathrm{O}$ & & $\begin{array}{l}-24.7,-26.6 \\
-28.9\end{array}$ \\
\hline \multicolumn{11}{|l|}{ Modeled climate } \\
\hline \multicolumn{3}{|l|}{ Mean annual temperature $\left({ }^{\circ} \mathrm{C}\right)$} & 21.0 & 18.1 & 15.4 & 12.8 & 12.3 & 12.2 & 9.7 & \\
\hline \multicolumn{3}{|c|}{ Mean annual precipitation (mm) } & 4,514 & 5,840 & 4,320 & 2,840 & 2,420 & 2,360 & 1,510 & \\
\hline \multicolumn{3}{|c|}{ Mean annual vapor pressure deficit $(\mathrm{kPa})$} & 0.573 & 0.369 & 0.318 & 0.352 & 0.365 & 0.366 & 0.430 & \\
\hline
\end{tabular}

Species nomenclature follows Staples et al. (2004); family nomenclature follows Tropicos, Missouri Botanical Garden [http://www.tropicos.org/ ]. Lava age is designated as 'young' (Y) for 1855-1881 flows and 'old' $(\mathrm{O})$ for the 3,400-year-old lava flow (and the ca. 400-year-old lava flow at the $1,750 \mathrm{~m}$ site). $R$. lanuginosum was present but not sampled at the $2,200 \mathrm{~m}$ site because of difficulties distinguishing live from dead material

independently, and for each of the six taxa that were sampled at six or more sites (five species: A. fuscoflacum, Bazzania cf. trilobata, D. speirophyllum, M. microstomum, $R$. lanuginosum; and one genus, Campylopus). The $\delta^{13} \mathrm{C}$ relationship with OC was tested across substrate types using raw data rather than species means because a single species could be found on several substrates within a single site.

For relationships that were significant for all species across all sites and also for individual soil ages and/or for more than one individual taxon, we tested for shifts in the relationship. We tested for similarity of the slope and intercept between the soil ages or among taxa, using untransformed or log-transformed data according to which fitted best the relationship for all species across all sites (using SMATR; http://www.bio.mq.edu.au/ecology/SMATR; Warton et al. 2006). Ordinary least squares regression was used for testing relationships between $\delta^{13} \mathrm{C}$ and climate variables or OC, and standard major axes were used in testing relationships between $\delta^{13} \mathrm{C}$ and structure and composition traits, as appropriate given co-dependence of variables (Sokal and Rohlf 1995).

When bryophyte traits were correlated with climate variables that were themselves inter-correlated, we calculated partial correlations to resolve underlying relationships (using the corpcor package in R; Schaefer et al. 2007).

\section{Results}

Species varied strongly in $\delta^{13} \mathrm{C}$; average values for species collected from at least four sites ranged from $-26.3 \% \pm 0.4$ for $R$. lanuginosum to $-31.2 \% \pm 0.4$ for L. gracile. Additionally, individual taxa varied strongly in $\delta^{13} \mathrm{C}$ across sites; for $R$. lanuginosum, $\delta^{13} \mathrm{C}$ differed by $4.2 \%$ from 300 to $1,650 \mathrm{~m}$ elevation on young soil, and within the genus Campylopus, $\delta^{13} \mathrm{C}$ differed by $5.5 \%$ from C. exasperatus at $700 \mathrm{~m}$ to $C$. hawaiicus at $1,100 \mathrm{~m}$ (Table 1). Across all 


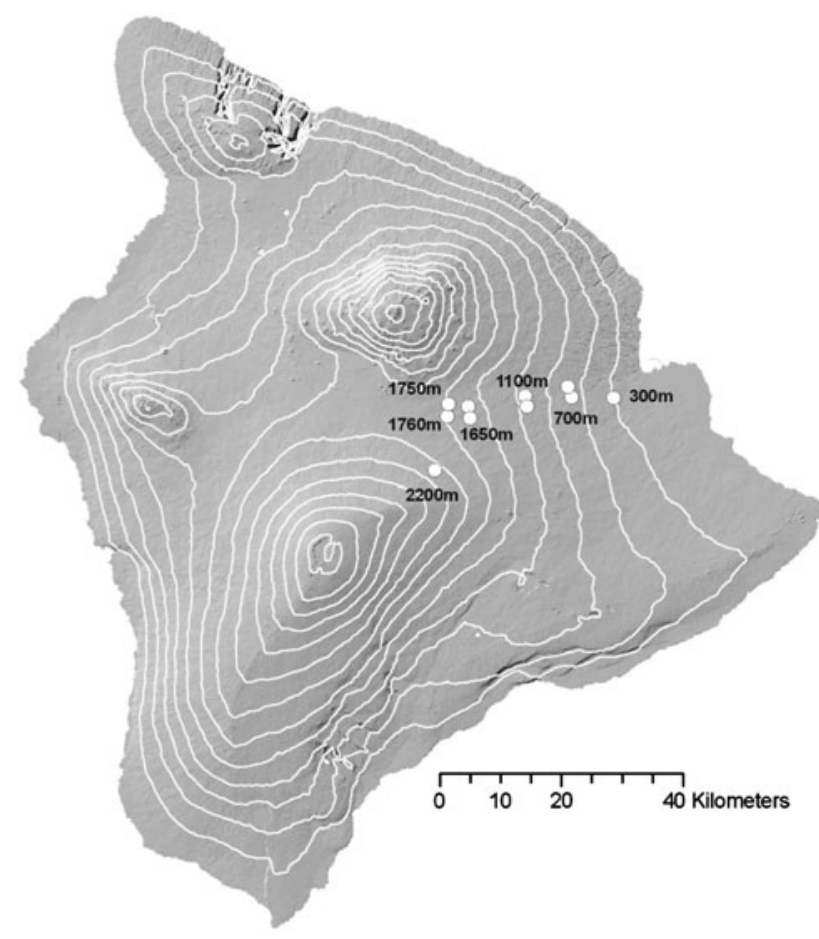

Fig. 1 Topographic map of Hawaii Island with 300-m elevational contour lines and sampling locations with elevations

sampled colonies, the $\delta^{13} \mathrm{C}$ showed significant differences across taxa, elevations and soil ages (three-way ANOVA; $P<0.001$ for each factor), with less negative values at higher elevation and on younger soil (Appendix Table A); on average the bryophytes on young and old soil had $\delta^{13} \mathrm{C}$ of $-28.7 \%$ o \pm 0.5 and $-29.7 \%$ o \pm 0.2 , respectively. Notably, all the climate variables correlated with elevation (for MAT, $r=-0.999$; for MAP, $r=-0.89$; for VPD, $r=-0.68$; $P<0.001)$, and MAT correlated with MAP $(r=0.92$, $P<0.001)$ and VPD $(r=0.53, P<0.001)$, though MAP was independent of VPD $(r=0.11, P=0.45$; Table 2). Across all the species and sites, $\delta^{13} \mathrm{C}$ correlated positively with elevation and negatively with MAT $(|r|=0.31-0.32$, $P<0.05$; Fig. 2a) but not significantly with MAP or VPD ( $r=-0.23$ to $-0.25 ; P=0.07-0.10$; Fig. $2 b$ ). Across all sampled colonies, the $\delta^{13} \mathrm{C}$ showed significant differences across substrate type (one-way ANOVA; $P<0.001$ ) with colonies on the rock substrate showing $\delta^{13} \mathrm{C}$ values significantly higher than those on bark, humus and tree fern trunk (Tukey HSD; $P<0.001$ ) but no significant differences among other substrates (Tukey HSD; $P=0.08-0.99$; Appendix Table B).

Across sites, $\delta^{13} \mathrm{C}$ correlated negatively with $\mathrm{OC}(r=$ $-0.63, P<0.001$; Fig. 3a). In turn, OC was independent of elevation, MAT, MAP, and VPD $(r=0.09-0.22$, $P=0.12-0.52)$. Part of the effect may have related to soil age, as OC differed between young and old soil sites from 52 to $62 \%$ on average (three-way ANOVA; elevation,
$P=0.008$; substrate age, $P<0.001$; taxon, $P<0.001$ ), and, as described above, $\delta^{13} \mathrm{C}$ was higher on younger soil. However, the linkage of $\delta^{13} \mathrm{C}$ with OC also held on soils of given age (see below). The linkage of $\delta^{13} \mathrm{C}$ with $\mathrm{OC}$ also held on most individual substrates (bark, leaf litter, and rock) for which there were more than four samples $(r=0.45-0.68, \quad P<0.001$; Appendix Table B); the exception was on humus $(r=0.29, P=0.14)$. The $\delta^{13} \mathrm{C}$ did not correlate with sampling height $(r=-0.08$, $P=0.58$; a typical value of $0.4 \mathrm{~m}$ was used for non-epiphytic species on ground, rocks or logs).

Across all species and sites, $\delta^{13} \mathrm{C}$ correlated with CMA and $N_{\text {area }} \quad(r=0.32-0.37, \quad P=0.01-0.02 ; \quad$ Fig. $3 \mathrm{~b}$; Table 2). However, $\delta^{13} \mathrm{C}$ was independent of bryophyte $\mathrm{CH}$, canopy density, and other nutrient traits $\left(N_{\text {mass }}, P_{\text {area }}\right.$, $P_{\text {mass }}, \mathrm{N}: \mathrm{P}, \mathrm{C}: \mathrm{N}$, and C:P; $\left.|r|=0.03-0.26, P=0.06-0.81\right)$.

The relationships of $\delta^{13} \mathrm{C}$ with elevation, climate, morphology and composition that held across all sites were similar when calculated only for sites on young or old substrates. Thus, on both young and old soil ages considered independently, $\delta^{13} \mathrm{C}$ correlated with elevation ( $r=-0.53$ to $-0.54, \quad P<0.001-0.02), \quad$ MAT $\quad(r=0.55-0.54, \quad P<$ $0.001-0.02)$, and OC $(r=0.42-0.75, P<0.001-0.01)$, but not with bryophyte $\mathrm{CH}$, density, or nutrient composition $\left(N_{\text {area }}, N_{\text {mass }}, P_{\text {area }}, P_{\text {mass }}, \quad \mathrm{N}: \mathrm{P}, \mathrm{C}: \mathrm{P}, \mathrm{CH}\right.$, and $\mathrm{CD}$ $(|r|<0.01-0.32, P=0.06-0.81)$. The slopes of $\delta^{13} \mathrm{C}$ against elevation and MAT were similar for both soil ages $(P=0.65-0.69)$ with higher intercepts for the young soil $(P<0.001)$. For $\delta^{13} \mathrm{C}$ against $\mathrm{OC}$, the two soil ages showed the same relationship (i.e., similar slopes and intercepts; $P=0.28-0.36$ ). However, in contrast with the data for all species and sites, on the young but not the old soil sites, $\delta^{13} \mathrm{C}$ correlated negatively with VPD and CMA ( $r=-0.50$ to $-0.55, P=0.02-0.03$ ), and on old but not on young soil, $\delta^{13} \mathrm{C}$ correlated positively with $\mathrm{C}: \mathrm{N}$ and negatively with MAP $(|r|=0.35-0.55, P<0.001-0.04)$.

When the taxa that occurred at six or more sites were analyzed separately, due apparently to the much lower variation in $\delta^{13} \mathrm{C}$ (Table 1), the only significant correlation of $\delta^{13} \mathrm{C}$ and an environmental or compositional trait was with OC for Campylopus and $R$. lanuginosum $(r=-0.84$, $P<0.05)$; the two taxa had similar slopes $(P=0.25)$ with the higher intercept for $R$. lanuginosum $(P<0.001)$. All other species showed non-significant empirical trends for this relationship ( $r=-0.43$ to $-0.73 ; P>0.05$ ).

Partial correlation analyses were used to resolve the relationships of $\delta^{13} \mathrm{C}$ with OC, MAT, and MAP, keeping other variables constant. The correlations of $\delta^{13} \mathrm{C}$ with $\mathrm{OC}$ and MAT could be resolved as independent effects; the correlation with OC remained significant after partialing out the effects of MAT and MAP $\left(r_{\text {partial }}=-0.61\right.$; $P<0.001$; Table 3), and the correlation with MAT remained significant after partialing out the effect of OC 
Table 2 Correlations of $\delta{ }^{13} \mathrm{C}$ with other measured traits from all sites, from young sites, old sites, and for given taxa

\begin{tabular}{|c|c|c|c|c|c|}
\hline & \multirow{2}{*}{$\begin{array}{l}\text { All species/all } \\
\text { sites }(n=53)\end{array}$} & \multirow{2}{*}{$\begin{array}{l}\text { All species/young } \\
\text { soil }(n=17)\end{array}$} & \multirow{2}{*}{$\begin{array}{l}\text { All species/old } \\
\text { soil }(n=33)\end{array}$} & \multicolumn{2}{|l|}{ Within-species } \\
\hline & & & & CAMP $(n=6)$ & $\operatorname{RALA}(n=6)$ \\
\hline Sampling height above ground & $-0.08(n=51)$ & -0.03 & $-0.11(n=31)$ & & \\
\hline \multicolumn{6}{|l|}{ Climate variables } \\
\hline Elevation & $0.31 *$ & $0.56^{*}$ & $0.54 * * *$ & 0.07 & 0.40 \\
\hline Mean annual temperature & $-0.32 *$ & $-0.55 *$ & $-0.54 * * *$ & -0.08 & -0.44 \\
\hline Mean annual precipitation & -0.25 & -0.14 & $-0.55 * * *$ & -0.04 & 0.01 \\
\hline Vapor pressure deficit (absolute) & -0.23 & $-0.55 *$ & 0.17 & 0.21 & -0.81 \\
\hline Overstory cover & $-0.63 * * *$ & $-0.75^{* * *}$ & $-0.42 *$ & $-0.89 *$ & $-0.84 *$ \\
\hline \multicolumn{6}{|l|}{ Canopy morphology and composition } \\
\hline Canopy height & $0.15(n=49)$ & $-0.09(n=13)$ & 0.28 & $-0.82(n=5)$ & $-0.52(n=4)$ \\
\hline Canopy mass per area & $0.37 * *$ & $0.50 *$ & 0.27 & 0.52 & 0.01 \\
\hline Canopy density & $0.13(n=49)$ & $0.32(n=13)$ & 0.00 & $0.65(n=5)$ & $0.27(n=4)$ \\
\hline Nitrogen per mass & -0.20 & -0.23 & -0.22 & 0.09 & -0.39 \\
\hline Nitrogen per area & $0.32 *$ & 0.40 & 0.21 & 0.61 & -0.13 \\
\hline Phosphorus per mass & -0.03 & 0.16 & -0.09 & 0.75 & -0.02 \\
\hline Phosphorus per area & 0.27 & 0.38 & 0.17 & 0.67 & 0.03 \\
\hline Nitrogen:phosphorus ratio & -0.05 & -0.19 & -0.17 & -0.47 & 0.11 \\
\hline Carbon:nitrogen ratio & 0.26 & 0.19 & $0.35 *$ & -0.19 & 0.34 \\
\hline Carbon:phosphorus ratio & 0.14 & 0.06 & 0.05 & -0.77 & 0.27 \\
\hline
\end{tabular}

Pearson correlation coefficients, with italicized values derived from log-transformed data, providing better fit and stronger significance. Replication is provided in parentheses in the first row, with exceptions denoted in the table

CAMP Campylopus spp., RALA Racomitrium lanuginosum

Significant correlations in bold: * $P<0.05$; ** $0.01 \geq P>0.001$; *** $P \leq 0.001$. No within-species correlations were found for Acroporium fuscoflavum $(n=7)$ Bazzania cf. trilobata $(n=7)$ Dicranum speirophyllum $(n=6)$ or Macromitrium microstomum $(n=9)$

Fig. 2 Relationship between bryophyte $\delta^{13} \mathrm{C}$ and a elevation and $\mathbf{b}$ mean annual precipitation (MAP) on Mauna Loa, Hawaii. Open and closed symbols represent colonies on young and soil, respectively. Linear regression fitted to data in (a) $\delta^{13} \mathrm{C}=-30.6$ $+0.00104 \times$ elevation. $* P<0.05$
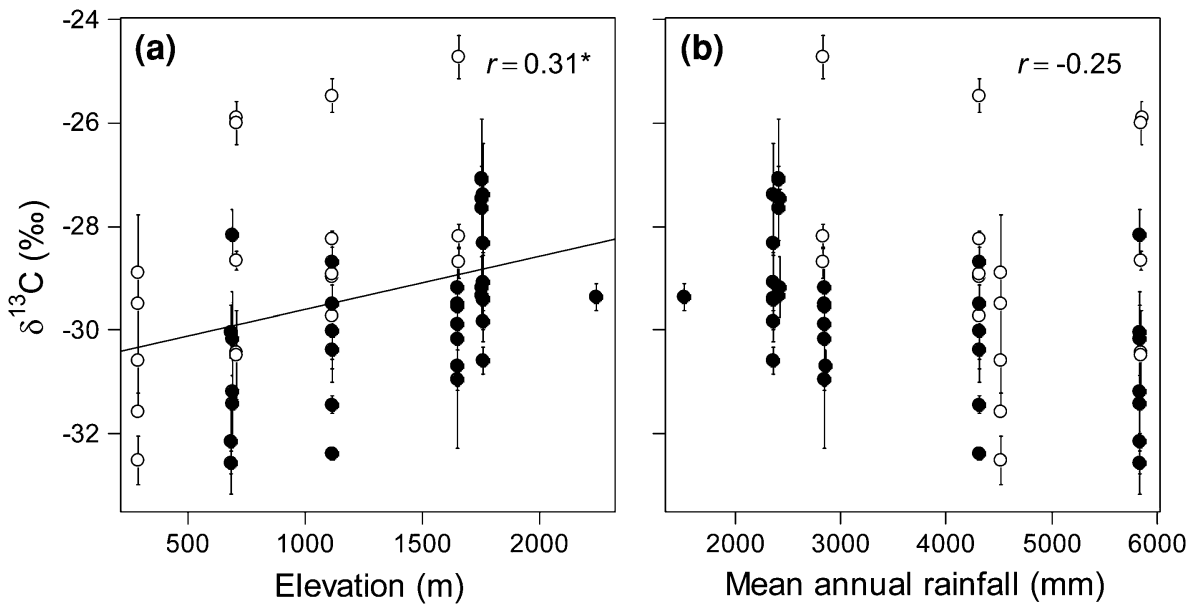

when log-transformed data were analyzed $\left(r_{\text {partial }}=-0.28\right.$; $P<0.05$; Table 3). Notably, the relationship of $\delta^{13} \mathrm{C}$ with MAT lost significance after partialing out MAP, as did that with MAP after partialing out MAT $\left(r_{\text {partial }}=-0.15\right.$ to 0.03 ; $P=0.29-0.83$; Table 3 ); thus, elevation, MAT and MAP could not be independently resolved as drivers of $\delta^{13} \mathrm{C}$, given their inter-correlation across the Mauna Loa matrix.
Partial correlation analyses were also used to resolve the relationships of $\delta^{13} \mathrm{C}$ with $\mathrm{OC}, \mathrm{CMA}$, and $N_{\text {area }}$, because $N_{\text {area }}$ and CMA were correlated $(r=0.91 ; P<0.001)$, and both were negatively correlated with OC $(r=-0.46$ to $-0.37 ; P<0.001-0.006)$. The relationship of $\delta^{13} \mathrm{C}$ with OC remained significant after partialing out CMA and $N_{\text {area }}$ ( $r_{\text {partial }}=-0.57 ; P<0.001$; Table 3$)$. However, the relationship of $\delta^{13} \mathrm{C}$ with CMA or $N_{\text {area }}$ lost significance after 

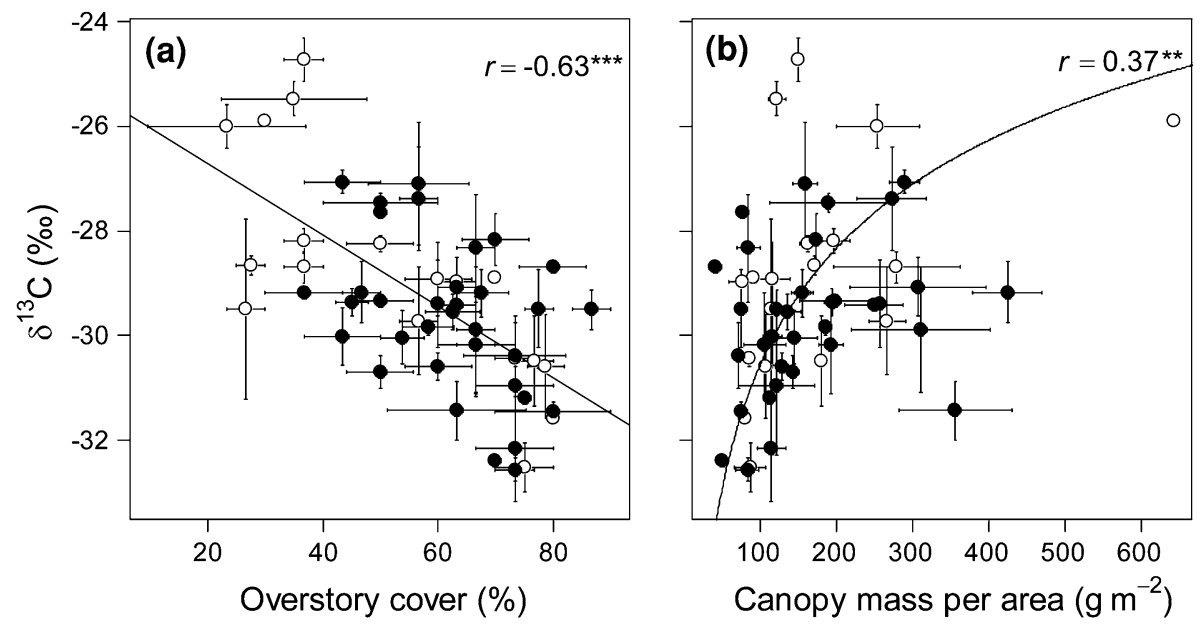

Fig. 3 Relationship between bryophyte $\delta^{13} \mathrm{C}$ and a elevation overstory cover (OC), and b bryophyte canopy mass per area (CMA). Open and closed symbols represent colonies on young and soil, respectively. Linear regression fitted to data in (a) $\delta^{13} \mathrm{C}=-25.3$ $-0.068 \times$ OC. Standard major axis power law fitted to data in (b) $\log \left(-1 \times \delta^{13} \mathrm{C}\right)=1.70-0.110 \times \log$ CMA. The correlation in

(b) remained significant when the outlier at the right was removed $(r=0.30, P=0.03)$. ${ }^{* *} 0.01 \geq P>0.001 ; * * * P \leq 0.001$. Notably, the relationship between $\delta^{13} \mathrm{C}$ and CMA appeared due to both variables being associated with OC; see partial correlation analysis in Table 3, and text

Table 3 Partial correlation analyses of $\delta^{13} \mathrm{C}$ and environmental variables

\begin{tabular}{|c|c|c|c|c|c|c|}
\hline & $\mathrm{OC}$ & Elevation & MAT & MAP & CMA & $N_{\text {area }}$ \\
\hline 1 & $-0.63 * * *$ & $0.31^{*}$ & & & & \\
\hline 2 & $-0.62 * * *$ & & $-0.28^{*}$ & & & \\
\hline 3 & $-0.61 * * *$ & & -0.15 & 0.03 & & \\
\hline 4 & & & -0.21 & 0.06 & & \\
\hline 5 & $-0.57 * * *$ & & & & 0.03 & 0.03 \\
\hline 6 & $-0.57 * * *$ & & & & 0.12 & \\
\hline 7 & $-0.59 * * *$ & & & & & 0.12 \\
\hline
\end{tabular}

Each row represents a separate partial correlation analysis of $\delta^{13} \mathrm{C}$ with the factors in the columns, partialling out the effect of all the other factor(s) in that row. For example, the first value in row (1) presents the partial correlation of $\delta^{13} \mathrm{C}$ and $\mathrm{OC}$, controlling for the effect of elevation

Values in italics were derived from log-transformed data (see Materials and methods)

Bold type indicates correlations that remained significant after partialling out the other factor(s)

CMA, canopy mass per area; MAP, mean annual precipitation; MAT, mean annual temperature; $N_{\text {area }}$, nitrogen per area; OC, overstory cover

Significance: $* P<0.05$, ** $0.01 \geq P>0.001, * * * P \leq 0.001$. The correlations with elevation and MAT remained significant after partialling out the effect of $\mathrm{OC}$ for $\log$-transformed data but not untransformed data. Correlations shown without significance were non-significant using log-transformed or untransformed data

the other was partialed out, or after OC was partialed out $\left(r_{\text {partial }}=0.03-0.12 ; P=0.40-0.83\right.$; Table 3$)$.

\section{Discussion}

Across the Mauna Loa matrix landscape, the bryophytes varied greatly in $\delta^{13} \mathrm{C}$ due to species differences and their

being located across sites ranging markedly in elevation, climate and soil age. Across the landscape, the bryophytes exhibited similar correlations of $\delta^{13} \mathrm{C}$ with elevation and habitat irradiance as previously reported for tracheophytes. This finding indicates a potential for parallel underlying processes, despite the lack of stomata in the dominant bryophyte gametophyte life stage, and provides insights into functional relationships. These trends in bryophytes have previously been reported within a few individual species, primarily in the genus Sphagnum (Menot and Burns 2001; Fletcher et al. 2006; Skrzypek et al. 2007). Our study extends these findings across 12 species within eight genera, across natural gradients at a landscape scale. Notably, the bryophytes on Mauna Loa showed only a weak, non-significant negative correlation of $\delta^{13} \mathrm{C}$ with rainfall (MAP), despite its nearly three-fold variation, thus suggesting no important "liquid water film effect" integrated over long-term growth across sites. This finding contrasts with positive trends of $\delta^{13} \mathrm{C}$ with water availability previously reported in studies of Sphagnum species across varying water table heights and moisture contents (Proctor et al. 1992; Rice and Giles 1996; Williams and Flanagan 1996; Loisel et al. 2009) and precipitation (Menot and Burns 2001; Zhu et al. 2009). Notably, Sphagnum species are unusual among mosses in having photosynthetic cells that are surrounded by dead, hollow cells that hold water and would contribute to greater $\mathrm{CO}_{2}$ diffusion resistance. Without such modified water-holding cells, the leaves of typical bryophyte species may quickly drain to an optimal water content less restrictive to $\mathrm{CO}_{2}$ diffusion (Dilks and Proctor 1979). Of the study taxa, only Leucobryum has a cellular morphology approaching that of Sphagnum. 
Potential sources of the $\delta^{13} \mathrm{C}$-elevation correlation

The landscape-scale increase of $\delta^{13} \mathrm{C}$ with elevation in bryophytes on Mauna Loa was similar to that of $M$. polymorpha trees at these sites (Vitousek et al. 1990; Cordell et al. 1998, 1999) and that observed generally for vascular plants along elevational gradients worldwide (Körner et al. 1988, 1991, 2003; Morecroft et al. 1992; Hikosaka et al. 2002). This finding extends the elevational trends reported for Sphagnum (Menot and Burns 2001; Skrzypek et al. 2007) to a broader set of genera. In vascular plants, the trend was attributed to reduced $\mathrm{CO}_{2}$ partial pressure, associated with the lower atmospheric pressure at higher elevations, which would reduce $\mathrm{c}_{\mathrm{c}}$ and increase $\delta^{13} \mathrm{C}$ (Körner et al. 1991), but later work concluded that such an effect would be too small to explain observed variation (Terashima et al. 1995; Körner 2003, 2007). The trend in vascular plants has also been attributed to increased leaf mass per area (LMA) with elevation (Körner 1989, 2003; Vitousek et al. 1990; Cordell et al. 1998; Hikosaka et al. 2002; Takahashi and Miyajima 2008; Li et al. 2009). A higher LMA in vascular plants may lead to lower mesophyll conductance, lower ratio of chloroplast to atmospheric $\mathrm{CO}_{2}$ partial pressure $\left(c_{\mathrm{c}} / c_{\mathrm{a}}\right.$ ) and higher $\delta^{13} \mathrm{C}$ (Terashima et al. 1995) because a greater leaf thickness increases the diffusion path length from the stomata to the mesophyll cell walls (Parkhurst 1994), and/or because thicker mesophyll cell walls reduce $\mathrm{CO}_{2}$ diffusion from intercellular air space to the chloroplasts (Niinemets 1999; Niinemets et al. 2009). We found that the $\delta^{13} \mathrm{C}$ decreased with decreasing bryophyte canopy mass per area (CMA), analogously to the decrease of $\delta^{13} \mathrm{C}$ with decreasing LMA in $M$. polymorpha (Vitousek et al. 1988), but whereas in $M$. polymorpha and in many other vascular plants LMA increases with elevation (Vitousek et al. 1988; Cordell et al. 1998; Hikosaka et al. 2002; Körner 2003), bryophyte CMA did not correlate with elevation but rather with OC (as discussed further below). These results indicate that the altitudinal trend in $\delta^{13} \mathrm{C}$ was likely due to lower $\mathrm{CO}_{2}$ pressure and/or the "temperature effect" as shown for three Sphagnum species (Menot and Burns 2001; Skrzypek et al. 2007). Such an effect contrasts with tracheophytes, for which there is no evidence for a general direct effect of temperature on $\delta^{13} \mathrm{C}$ (Troughton and Card 1975; Christeller et al. 1976). There is also the possibility that the declining cloud cover and thus increased irradiance, lower MAP and higher VPD at higher elevation might have contributed to the increase of $\delta^{13} \mathrm{C}$. However, we found no correlation of $\delta^{13} \mathrm{C}$ with MAP or VPD, and thus such an effect was apparently not important at the landscape scale.
Potential sources of the $\delta^{13} \mathrm{C}$-soil age and $\delta^{13} \mathrm{C}-\mathrm{OC}$ correlations

We observed a tendency for lower bryophyte $\delta^{13} \mathrm{C}$ on older soils on Mauna Loa. This finding is similar to that reported for leaves of $M$. polymorpha which have lower LMA and lower $\delta^{13} \mathrm{C}$ on the young flows (Vitousek et al. 1990). However, for the bryophytes, the effect was weak and apparently linked with the lower OC on young flows.

The strong correlation of bryophyte $\delta^{13} \mathrm{C}$ with OC across the landscape would likely have arisen from several factors. A first candidate is the "source air effect" if incomplete mixing resulted in air enriched in ${ }^{12} \mathrm{C}$ due to soil-respired $\mathrm{CO}_{2}$ at bryophyte-level at sites with higher $\mathrm{OC}$; such an effect would be stronger when canopies are dense, hindering airflow (Schleser and Jayasekera 1985; Broadmeadow et al. 1992). However, the bryophytes in this study were typically collected $<0.5 \mathrm{~m}$ above ground, and up to only $5.5 \mathrm{~m}$ above soil, and tissue $\delta^{13} \mathrm{C}$ did not correlate with vertical height as expected if soil respiration were a major driver of the $\delta^{13} \mathrm{C}-\mathrm{OC}$ relationship. The $\delta^{13} \mathrm{C}$ was significantly higher in colonies growing on rock than on organic substrates, as would be expected if substrate respiration had an important effect. However, colonies growing on humus, where substrate decomposition presumably leads to high $\mathrm{CO}_{2}$ production, did not differ significantly from those growing on bark substrates, and, most importantly, the $\delta^{13} \mathrm{C}-\mathrm{OC}$ relationship held on individual substrates, including on rock. Thus, a vertical gradient in source air composition would likely contribute as a subtle effect, rather than as key driver of the relationship. The strong gradient in irradiance was likely the primary driver of the relationship, as reported for leaves of tracheophytes within forests (Buchmann et al. 1997b; Sternberg et al. 1997) and within the canopies of single trees (Le Roux et al. 2001). The $\delta^{13} \mathrm{C}-\mathrm{OC}$ relationship may arise from the "irradiance-A effect" effect, i.e. a higher $\delta^{13} \mathrm{C}$ due to increased photosynthetic rate. The relationship might also arise from an indirect effect of water stress in more exposed, drier microhabitats leading to the development of thicker cell walls with greater water storage capacity, which during periods of high water availability would reduce $\mathrm{CO}_{2}$ diffusion (Dilks and Proctor 1979; Waite and Sack 2010). Such an effect may hold for individual species, but the lack of a significant relationship of $\delta^{13} \mathrm{C}$ with MAP or with VPD despite their varying by two- to three-fold across sites did not support the importance of such an effect at the landscape scale. We note that variation across taxa in cell size might also be expected to play a role; across three species of microalgae, larger cell size was related to reduced $\mathrm{CO}_{2}$ conductance and higher $\delta^{13} \mathrm{C}$ (Popp et al. 1998). That scenario is unlikely to be important across bryophyte species, in which larger cells tend to be 
associated with deeper shade (Waite and Sack 2010) while higher $\delta^{13} \mathrm{C}$ was related to lower $\mathrm{OC}$ and hence greater irradiance.

Thus, the results best support a direct effect of irradiance on photosynthetic rate as a key driver of the bryophyte $\delta^{13} \mathrm{C}-\mathrm{OC}$ relationship. Such an effect was found experimentally for two liverwort species grown at four irradiance levels; $\delta^{13} \mathrm{C}$ correlated positively with growth irradiance (Fletcher et al. 2006). Our findings extend this pattern across multiple species and show its potential importance at the landscape scale, across sites varying in forest successional stages. The effect is quantitatively strong; when the range of $\mathrm{OC}$ was divided into five bins, the average $\delta^{13} \mathrm{C}$ shifted from -27.1 to $-30.6 \%$. The effect was also strong on bark, leaf litter and rock substrates individually; the lack of the correlation on humus may be due to the lower range of $\mathrm{OC}$ values compared to the other substrate types. Notably, the correlation of OC and $\delta^{13} \mathrm{C}$ observed across all species and sites was also found within two of the six tested taxa, i.e., for Campylopus and in $R$. lanuginosum, which had the greatest range in OC values. Whereas these within-species relationships emerged from their wide distribution across OC levels, the across-species relationship reflected the assembly of diverse species along a light gradient (cf. Ackerly and Cornwell 2007).

We found that bryophyte $\delta^{13} \mathrm{C}$ correlated with the morphological variable CMA, analogously to LMA for tracheophyte leaves. This finding points to integrated adjustment of canopy form and physiology with irradiance for bryophytes across forest successional stages. However, by contrast with tracheophytes, in which the correlation of $\delta^{13} \mathrm{C}$ and LMA may arise in part from their relationship with mesophyll conductance, our partial correlation analysis indicated that in bryophytes, the relationship of $\delta^{13} \mathrm{C}$ with CMA arose indirectly due to relationships with OC. The high scatter in the correlation of $\delta^{13} \mathrm{C}$ with CMA, and their joint relationship with $\mathrm{OC}$ indicates that additional data would be needed to support a direct control of $\delta^{13} \mathrm{C}$ by CMA for any given species.

\section{Implications and future work}

The bryophytes of this study exhibited great similarities with vascular plants in landscape-scale patterns, showing independent and strong trends for lower carbon isotope fractionation with younger soil age, greater canopy openness and increasing elevation. The similarity with tracheophytes is especially remarkable given the centrality of stomata in explaining carbon isotope fractionation in tracheophytes and the lack of these structures in bryophytes. Our findings point to direct environmental impacts of light and temperature on gas exchange rates as primary mechanisms for these landscape-level trends. We inferred the importance of given potential effects from correlation analyses at landscape scale; individual species may differ in the factors that determine $\delta^{13} \mathrm{C}$. These findings highlight a necessity for additional mechanistic studies to clarify the underlying basis for these landscape-level trends. Indeed, for bryophytes, we lack a physiological predictor of $\delta^{13} \mathrm{C}$ signals, in the way that stomatal water use efficiency can be used for tracheophytes (reviewed in Seibt et al. 2008). This study, showing strong $\delta^{13} \mathrm{C}$ signals across the landscape scale, points to the importance of elucidating the determinants of carbon isotope discrimination in bryophyte structure and biochemistry (see Meyer et al. 2008). Such studies will need to determine isotope fractionation in real time for given species under ranges of controlled conditions to deepen the understanding of the landscape scale patterns demonstrated here.

We found the variation in $\delta^{13} \mathrm{C}$ in bryophytes at the landscape scale-including diverse taxa across diverse systems - to be information-rich, reflecting the signal of multiple environmental factors. This finding indicates the possibility of extending the usefulness of preserved bryophyte tissue to estimate past environmental conditions. Previous work emphasized that the lack of stomata can link bryophyte $\delta^{13} \mathrm{C}$ more closely with atmospheric $\mathrm{CO}_{2}$ concentration than for vascular plants (White et al. 1994; Fletcher et al. 2005, 2006, 2008), and pointed to the $\delta^{13} \mathrm{C}$ of fossilized Sphagnum as a proxy for moisture conditions, given that the "liquid film effect" would lead to higher $\delta^{13} \mathrm{C}$ in wetter climates (Loisel et al. 2009; Zhu et al. 2009). However, the lack of a relationship in our study between $\delta^{13} \mathrm{C}$ and MAP in the Mauna Loa bryophytes suggests that not all species would be good proxies for moisture conditions, though they may be proxies for other environmental factors. An avenue for future work is to determine how to model the combined effects of elevation, irradiance, soil age and temperature on given bryophyte floras. Alternatively, it may be possible to tease apart specific environmental signals, perhaps by using additional isotopes to carbon. Thus, bryophytes, by occupying, and responding to, a very wide range of environments could provide in their tissues recoverable information not only of physiological responses across gradients but also information of their climates and microhabitats.

Acknowledgments Tom Giambelluca assisted with climate data, Randi Schneider with nutrient analyses, and Posy Busby and Peter Vitousek with logistics. We thank Don Drake, Travis Idol, Shelley James, Ulli Seibt, Alison Sherwood and two anonymous reviewers and editor Robert Pearcy for helpful comments on the manuscript. This research was supported by NSF Grant \#0546784. 
Open Access This article is distributed under the terms of the Creative Commons Attribution Noncommercial License which permits any noncommercial use, distribution, and reproduction in any medium, provided the original author(s) and source are credited.

\section{References}

Ackerly DD, Cornwell WK (2007) A trait-based approach to community assembly: partitioning of species trait values into within- and among-community components. Ecol Lett 10:135-145

Barbour MM, Hanson DT (2009) Stable carbon isotopes reveal dynamics of respiratory metabolism. New Phytol 181:243-245

Bellow JG, Nair PKR (2003) Comparing common methods for assessing understory light availability in shaded-perennial agroforestry systems. Agric For Meteorol 114:197-211

Broadmeadow MSJ, Griffiths H, Maxwell C, Borland AM (1992) The carbon isotope ratio of plant organic material reflects temporal and spatial variations in $\mathrm{CO}_{2}$ within tropical forest formations in Trinidad. Oecologia 89:435-441

Brooks JR, Flanagan LB, Buchmann N, Ehleringer JR (1997) Carbon isotope composition of boreal plants: functional grouping of life forms. Oecologia 110:301-311

Buchmann N, Guehl JM, Barigah TS, Ehleringer JR (1997a) Interseasonal comparison of $\mathrm{CO}_{2}$ concentrations, isotopic composition, and carbon dynamics in an Amazonian rainforest (French Guiana). Oecologia 110:120-131

Buchmann N, Kao WY, Ehleringer J (1997b) Influence of stand structure on carbon-13 of vegetation, soils, and canopy air within deciduous and evergreen forests in Utah, United States. Oecologia 110:109-119

Buchmann N, Brooks JR, Ehleringer JR (2002) Predicting daytime carbon isotope ratios of atmospheric $\mathrm{CO}_{2}$ within forest canopies. Funct Ecol 16:49-57

Campbell GS, Norman JM (1998) Introduction to environmental biophysics. Springer, New York

Cao GX, Giambelluca TW, Stevens DE, Schroeder TA (2007) Inversion variability in the Hawaiian trade wind regime. J Clim 20:1145-1160

Christeller JT, Laing WA, Troughton JH (1976) Isotope discrimination by ribulose 1, 5-diphosphate carboxylase: no effect of temperature or $\mathrm{HCO}_{3}$-concentration. Plant Physiol 57:580-582

Cordell S, Goldstein G, Mueller-Dombois D, Webb D, Vitousek PM (1998) Physiological and morphological variation in Metrosideros polymorpha, a dominant Hawaiian tree species, along an altitudinal gradient: the role of phenotypic plasticity. Oecologia 113:188-196

Cordell S, Goldstein G, Meinzer FC, Handley LL (1999) Allocation of nitrogen and carbon in leaves of Metrosideros polymorpha regulates carboxylation capacity and $\delta^{13} \mathrm{C}$ along an altitudinal gradient. Funct Ecol 13:811-818

DeLucia EH et al (2003) The contribution of bryophytes to the carbon exchange for a temperate rainforest. Glob Change Biol 9:1158-1170

Dilks TJK, Proctor MCF (1979) Photosynthesis, respiration and water content in bryophytes. New Phytol 82:97-114

Duursma RA, Marshall JD (2006) Vertical canopy gradients in $\delta^{13} \mathrm{C}$ correspond with leaf nitrogen content in a mixed-species conifer forest. Trees-Struct Funct 20:496-506

Ehleringer JR, Field CB, Lin ZF, Kuo CY (1986) Leaf carbon isotope and mineral composition in subtropical plants along an irradiance cline. Oecologia 70:520-526
Farquhar GD, Sharkey TD (1982) Stomatal conductance and photosynthesis. Annu Rev Plant Physiol Plant Mol Biol 33:317-345

Farquhar GD, Ehleringer JR, Hubick KT (1989) Carbon isotope discrimination and photosynthesis. Annu Rev Plant Physiol Plant Mol Biol 40:503-537

Fletcher BJ, Beerling DJ, Chaloner WG (2004) Stable carbon isotopes and the metabolism of the terrestrial Devonian organism Spongiophyton. Geobiology 2:107-119

Fletcher BJ, Beerling DJ, Brentnall SJ, Royer DL (2005) Fossil bryophytes as recorders of ancient $\mathrm{CO}_{2}$ levels: experimental evidence and a Cretaceous case study. Glob Biogeochem Cycles 19:GB3012

Fletcher BJ, Brentnall SJ, Quick WP, Beerling DJ (2006) BRYOCARB: a process-based model of thallose liverwort carbon isotope fractionation in response to $\mathrm{CO}_{2}, \mathrm{O}_{2}$, light and temperature. Geochim Cosmochim Acta 70:5676-5691

Fletcher BJ, Brentnall SJ, Anderson CW, Berner RA, Beerling DJ (2008) Atmospheric carbon dioxide linked with Mesozoic and early Cenozoic climate change. Nature Geosci 1:43-48

Francey RJ, Gifford RM, Sharkey TD, Weir B (1985) Physiological influences on carbon isotope discrimination in Huon pine (Lagarostrobos franklinii). Oecologia 66:211-218

Fry B et al (1996) Cryoflow: cryofocusing nanomole amounts of $\mathrm{CO}_{2}$, $\mathrm{N}_{2}$, and $\mathrm{SO}_{2}$ from an elemental analyzer for stable isotopic analysis. Rapid Commun Mass Spectrom 10:953-958

Garten CT, Taylor GE (1992) Foliar $\delta^{13} \mathrm{C}$ within a temperate deciduous forest: spatial, temporal, and species sources of variation. Oecologia 90:1-7

Gillon JS, Griffiths H (1997) The influence of (photo)respiration on carbon isotope discrimination in plants. Plant Cell Environ 20:1217-1230

Hamerlynck EP, Csintalan Z, Nagy Z, Tuba Z, Goodin D, Henebry GM (2002) Ecophysiological consequences of contrasting microenvironments on the desiccation tolerant moss Tortula ruralis. Oecologia 131:498-505

Hikosaka K, Nagamatsu D, Ishii HS, Hirose T (2002) Photosynthesisnitrogen relationships in species at different altitudes on Mount Kinabalu, Malaysia. Ecol Res 17:305-313

Hultine KR, Marshall JD (2000) Altitude trends in conifer leaf morphology and stable carbon isotope composition. Oecologia 123:32-40

Jennings SB, Brown ND, Sheil D (1999) Assessing forest canopies and understorey illumination: canopy closure, canopy cover and other measures. Forestry 72:59-73

Juvik JO, Nullet D (1994) A climate transect through tropical montane rain-forest in Hawaii. J Appl Meteorol 33:1304-1312

Korhonen L, Korhonen KT, Rautiainen M, Stenberg P (2006) Estimation of forest canopy cover: a comparison of field measurement techniques. Silva Fenn 40:577-588

Körner C (1989) The nutritional status of plants from high altitudes: a world comparison. Oecologia 81:379-391

Körner C (2003) Alpine plant life: functional plant ecology of high mountain ecosystems, 2nd edn. Springer, Berlin

Körner C (2007) The use of 'altitude' in ecological research. Trends Ecol Evol 22:569-574

Körner C, Farquhar GD, Roksandic Z (1988) A global survey of carbon isotope discrimination in plants from high altitude. Oecologia 74:623-632

Körner C, Farquhar GD, Wong SC (1991) Carbon isotope discrimination by plants follows latitudinal and altitudinal trends. Oecologia 88:30-40

Le Roux X et al (2001) Spatial distribution of leaf water-use efficiency and carbon isotope discrimination within an isolated tree crown. Plant Cell Environ 24:1021-1032

Li CY, Wu CC, Duan BL, Korpelainen H, Luukkanen O (2009) Agerelated nutrient content and carbon isotope composition in the 
leaves and branches of Quercus aquifolioides along an altitudinal gradient. Trees-Struct Funct 23:1109-1121

Lockwood JP, Lipman PW, Peterson LD, Warshauer FR (1988) Generalized ages of surface flows of Mauna Loa Volcano, Hawaii. US Government Printing Office, Washington, DC

Loisel J, Garneau M, Helie JF (2009) Modern Sphagnum $\delta^{13} \mathrm{C}$ signatures follow a surface moisture gradient in two boreal peat bogs, James Bay lowlands, Quebec. J Quatern Sci 24:209-214

Loreto F, Harley PC, Dimarco G, Sharkey TD (1992) Estimation of mesophyll conductance to $\mathrm{CO}_{2}$ flux by 3 different methods. Plant Physiol 98:1437-1443

Medina E, Minchin P (1980) Stratification of $\delta^{13} \mathrm{C}$ values of leaves in Amazonian rain forests. Oecologia 45:377-378

Medina E, Sternberg L, Cuevas E (1991) Vertical stratification of $\delta^{13} \mathrm{C}$ values in closed natural and plantation forests in the Luquillo Mountains, Puerto Rico. Oecologia 87:369-372

Menot G, Burns SJ (2001) Carbon isotopes in ombrogenic peat bog plants as climatic indicators: calibration from an altitudinal transect in Switzerland. Org Geochem 32:233-245

Menot-Combes G, Combes PP, Burns SJ (2004) Climatic information from $\delta^{13} \mathrm{C}$ in plants by combining statistical and mechanistic approaches. Holocene 14:931-939

Meyer M, Seibt U, Griffiths H (2008) To concentrate or ventilate? Carbon acquisition, isotope discrimination and physiological ecology of early land plant life. Philos Trans R Soc Lond B 363:2767-2778

Miller RO (1998) High-temperature oxidation: dry ashing. In: Kalra YP (ed) Handbook of reference methods for plant analysis. CRC Press, Boca Raton, pp 53-56

Morecroft MD, Woodward FI, Marrs RH (1992) Altitudinal trends in leaf nutrient contents, leaf size and $\delta^{13} \mathrm{C}$ of Alchemilla alpina. Funct Ecol 6:730-740

Niinemets U (1999) Components of leaf dry mass per area-thickness and density-alter leaf photosynthetic capacity in reverse directions in woody plants. New Phytol 144:35-47

Niinemets U, Sonninen E, Tobias M (2004) Canopy gradients in leaf intercellular $\mathrm{CO}_{2}$ mole fractions revisited: interactions between leaf irradiance and water stress need consideration. Plant Cell Environ 27:569-583

Niinemets U, Wright IJ, Evans JR (2009) Leaf mesophyll diffusion conductance in 35 Australian sclerophylls covering a broad range of foliage structural and physiological variation. J Exp Bot 60:2433-2449

O'Leary MH (1988) Carbon isotopes in photosynthesis. Bioscience 38:328-336

Ometto $\mathrm{J}$ et al (2006) The stable carbon and nitrogen isotopic composition of vegetation in tropical forests of the Amazon Basin, Brazil. Biogeochemistry 79:251-274

Paletto A, Tosi V (2009) Forest canopy cover and canopy closure: comparison of assessment techniques. Eur J For Res 128:265-272

Parkhurst DF (1994) Diffusion of $\mathrm{CO}_{2}$ and other gases inside leaves. New Phytol 126:449-479

Popp BN, Laws EA, Bidigare RR, Dore JE, Hanson KL, Wakeham SG (1998) Effect of phytoplankton cell geometry on carbon isotopic fractionation. Geochim Cosmochim Acta 62:69-77

Porder S, Paytan A, Vitousek PM (2005) Erosion and landscape development affect plant nutrient status in the Hawaiian Islands. Oecologia 142:440-449

Proctor MCF, Raven JA, Rice SK (1992) Stable carbon isotope discrimination measurements in Sphagnum and other bryophytes: physiological and ecological implications. J Bryol 17:193-202

Raich JW, Russell AE, Vitousek PM (1997) Primary productivity and ecosystem development along an elevational gradient on Mauna Loa, Hawaii. Ecology 78:707-721
Rice SK, Giles L (1996) The influence of water content and leaf anatomy on carbon isotope discrimination and photosynthesis in Sphagnum. Plant Cell Environ 19:118-124

Rundel PW, Stichler W, Zander RH, Ziegler H (1979) Carbon and hydrogen isotope ratios of bryophytes from arid and humid regions. Oecologia 44:91-94

Schaefer J, Opgen-Rhein R, Strimmer K (2007) corpcor: Efficient estimation of covariance and (partial) correlation. $\mathrm{R}$ package version 1.4 .7

Schedlbauer JL, Kavanagh KL (2008) $\delta^{13} \mathrm{C}$ in Pentaclethra macroloba trees growing at forest edges in north-eastern Costa Rica. J Trop Ecol 24:49-56

Schleser GH, Jayasekera R (1985) $\delta^{13} \mathrm{C}$-variations of leaves in forests as an indication of reassimilated $\mathrm{CO} 2$ from the soil. Oecologia 65:536-542

Schofield WB (1985) Introduction to bryology. Macmillan, New York

Schott MR, Pieper RD (1985) Influence of canopy characteristics of one-seed juniper on understory grasses. J Range Manag 38:328-331

Seibt U, Rajabi A, Griffiths H, Berry JA (2008) Carbon isotopes and water use efficiency: sense and sensitivity. Oecologia 155:441-454

Skrzypek G, Kaluzny A, Wojtun B, Jedrysek MO (2007) The carbon stable isotopic composition of mosses: a record of temperature variation. Org Geochem 38:1770-1781

Sokal RR, Rohlf FJ (1995) Biometry, 3rd edn. Freeman, New York

Staples GW, Imada CT, Hoe WT, Smith CW (2004) A revised checklist of Hawaiian mosses. Trop Bryol 25:35-69

Sternberg LDL, Mulkey SS, Wright SJ (1989) Ecological interpretation of leaf carbon isotope ratios: influence of respired carbon dioxide. Ecology 70:1317-1324

Sternberg LDS et al (1997) Carbon dioxide recycling in two Amazonian tropical forests. Agric For Meteorol 88:259-268

Takahashi K, Miyajima Y (2008) Relationships between leaf life span, leaf mass per area, and leaf nitrogen cause different altitudinal changes in leaf $\delta^{13} \mathrm{C}$ between deciduous and evergreen species. Botany 86:1233-1241

R Development Core Team (2007) R: a language and environment for statistical computing. R Foundation for Statistical Computing, Vienna, Austria

Terashima I, Masuzawa T, Ohba H, Yokoi Y (1995) Is photosynthesis suppressed at higher elevations due to low $\mathrm{CO}_{2}$ pressure? Ecology 76:2663-2668

Teti PA, Pike RG (2005) Selecting and testing an instrument for surveying stream shade. BC J Ecosyst Manag 6:1-16

Troughton JH, Card KA (1975) Temperature effects on carbonisotope ratio of $\mathrm{C}_{3}, \mathrm{C}_{4}$ and Crassulacean-acid-metabolism (CAM) plants. Planta 123:185-190

Vitousek PM (2004) Nutrient cycling and limitation: Hawaii as a model system. Princeton University Press, Princeton

Vitousek PM, Matson PA, Turner DR (1988) Elevational and age gradients in Hawaiian montane rainforest: foliar and soil nutrients. Oecologia 77:565-570

Vitousek PM, Field CB, Matson PA (1990) Variation in foliar $\delta^{13} \mathrm{C}$ in Hawaiian Metrosideros plolymorpha: a case of internal resistance. Oecologia 84:362-370

Vitousek PM, Aplet GH, Raich JW, Lockwood JP (1995) Biological perspectives on Mauna Loa Volcano: a model system for ecological research. In: Rhodes JM, Lockwood JP (eds) Mauna Loa revealed: structure, composition, history, and hazards. American Geophysical Union, Washington DC, pp 117-126

Vora RS (1988) A comparison of the spherical densiometer and ocular methods of estimating canopy cover. Great Basin Natur 48:224-227

Waite M, Sack L (2010a) How does moss photosynthesis relate to leaf and canopy structure? Trait relationships for 10 Hawaiian species of contrasting light habitats. New Phytol 185:156-172 
Waite M, Sack L (2011) Does global stoichiometric theory apply to bryophytes? Tests across and elevation $\times$ soil age ecosystem matrix on Mauna Loa, Hawaii. J Ecol 99:122-134

Warton DI, Wright IJ, Falster DS, Westoby M (2006) Bivariate linefitting methods for allometry. Biol Rev 81:259-291

White JWC, Ciais P, Figge RA, Kenny R, Markgraf V (1994) A high resolution record of atmospheric $\mathrm{CO}_{2}$ content from carbon isotopes in peat. Nature 367:153-156
Williams TG, Flanagan LB (1996) Effect of changes in water content on photosynthesis, transpiration and discrimination against ${ }^{13} \mathrm{CO}_{2}$ and $\mathrm{C}^{18} \mathrm{O}^{16} \mathrm{O}$ in Pleurozium and Sphagnum. Oecologia 108:38-46

Zar JH (1999) Biometry. Prentice Hall, Upper Saddle River

Zhu Y et al (2009) Record of environmental change by alphacellulose $\delta 13 \mathrm{C}$ of sphagnum peat at Shennongjia, 4,0001,000 aBP. Chin Sci Bull 54:3731-3738 